\title{
STUDI WISATA PENGAMATAN BURUNG (BIRDWATCHING) DI LAHAN BASAH DESA KIBANG PACING KECAMATAN MENGGALA TIMUR KABUPATEN TULANG BAWANG PROVINSI LAMPUNG
}

\author{
(STUDY TOURISM OF OBSERVATIONS BIRD \\ (BIRDWATCHING) IN WETLAND KIBANG PACING \\ EAST MENGGALA DISTRICT TULANG BAWANG REGENCY LAMPUNG \\ PROVINCE)
}

\author{
Enal Kurniawan, Sugeng P. Harianto, dan Rusita \\ Jurusan Kehutanan Fakultas Pertanian Universitas Lampung \\ Jl. Soemantri Brojonegoro No. 1 Bandar Lampung \\ E-mail : kurniawanena19999@gmail.com \\ Phone : +6281373403808
}

\begin{abstract}
ABSTRAK
Indonesia memiliki areal lahan basah yang cukup luas, $21 \%$ dari luas daratannya adalah lahan basah dengan luasan lebih dari 38 juta hektar. Desa Kibang Pacing Kecamatan Menggala Timur merupakan salah satu lahan basah di Provinsi Lampung yang memiliki kekayaan jenis burung sejumlah 40 spesies dari 21 famili (Triyanah, 2014). Kekayaan jenis burung tersebut perlu dilakukan inventarisasi kembali dengan melakukan penelitian lanjutan untuk mengetahui jenis burung yang potensial dijadikan objek wisata pengamatan burung (birdwatching) dilihat dari status konservasi dan status ekologinya. Penelitian ini bertujuan untuk mengetahui jenis burung yang potensial dijadikan objek wisata birdwatching dan membandingkan dengan penelitian sebelumnya yang dilakukan oleh Triyanah pada tahun 2014, mengetahui pengaruh kondisi habitat dan tipe vegetasi terhadap keberadaan dan aktivitas burung, serta mengetahui persepsi masyarakat mengenai wisata birdwatching. Metode yang digunakan dalam penelitian ini adalah metode point count, rapid assessment, dan wawancara semiterstruktur. Analisis data dilakukan melalui analisis deskriptif. Hasil penelitian ditemukan 27 jenis burung yang masuk dalam kategori endemik dan hanya 13 jenis burung yang masuk dalam kategori dilindungi. Kondisi habitat dan tipe vegetasi sangat berpengaruh terhadap keberadaan dan aktivitas burung. Keberadaan burung paling banyak ditemukan pada tipe vegetasi gelam yang kondisi habitatnya baik dengan sumber pakan yang melimpah sehingga aktivitas burung ditemukan paling banyak mencari makan. Masyarakat mendukung sepenuhnya untuk pengembangan wisata birdwatching di Desa Kibang Pacing. Penelitian ini diharapkan dapat menjadi dasar pengembangan wisata birdwatching di Desa Kibang Pacing.
\end{abstract}

Kata kunci: birdwatching, Kibang Pacing, lahan basah

\section{ABSTRACT}

Indonesia have a wide wetland area, $21 \%$ of its lands area is a wetland comprising more than 38 million hectare. Kibang pacing village at east menggala district is one of the wetlands in the lampung province that have a plenty species of bird comprising 40 species of 21 families (Triyanah, 2014). Further research was needed to determine the potential bird species that will be used as attraction bird (birdwatching) in terms of its conservation status 


\section{Vol. 5 No.I, Januari 2017 (35-46)}

and ecological status. This research was aimed to determine the potential bird that will be used as birdwatching object, compare the result with the former research result that has been done by Triyanah at 2014, determine the effect of habitat conditions and vegetation type to the existence and activity of the bird, and knowing society perception about birdwatching. Tis research was using point count method, rapid assessment, and semistructured interview. The research found 27 endemic species of birds and 13 species of birds categorized as protected. Habitat condition and vegetation type was affecting the presence and birds activity. Most of the birds was found in gelam vegetation because there was a plenty source of food. Society was fully support the development of birdwatching tourism in the kibang pacing village.

Keywords: Birdwatching, Kibang pacing, wetland

\section{PENDAHULUAN}

Indonesia memiliki areal lahan basah yang cukup luas, $21 \%$ dari luas daratannya adalah lahan basah dengan luasan lebih dari 38 juta hektar. Desa Kibang Pacing Kecamatan Menggala Timur adalah salah satu lahan basah yang terletak di Provinsi Lampung. Menurut penilitian sebelumnya yang dilakukan oleh Triyanah pada tahun 2014, kekayaan burung yang terdapat di Desa Kibang Pacing sejumlah 40 jenis burung dengan total 1986 individu yang berasal dari 21 famili. Kekayaan jenis burung tersebut jika dimanfaatkan untuk objek wisata birdwatching akan memberikan dampak positif bagi masyarakat di sekitarnya. Kegiatan wisata alam birdwatching ini, di satu sisi bisa memberikan manfaat ekonomi bagi masyarakat sekitar karena banyaknya wisatawan yang akan melakukan kunjungan ke daerah tersebut, di sisi lain juga bisa memberikan manfaat konservasi bagi jenis-jenis burung (Widyasari, 2013). Jika ingin dijadikan objek wisata birdwatching maka perlu dilakukan inventarisasi jenis burung yang potensial untuk dijadikan wisata birdwatching yang menggunakan dua kriteria yaitu: jenis burung endemik dan jenis burung yang dilindungi. Jenis burung yang potensial untuk dijadikan sebagai objek wisata birdwatching ditentukan berdasarkan status konservasi dan endemisitas (Sukara, 2014).

Penelitian ini merupakan penelitian lanjutan dari penelitian Triyanah pada tahun 2014 di lahan basah Desa Kibang Pacing Kecamatan Menggala Timur. Hasil dari penelitian ini diharapkan dapat menjadi dasar pengembangan wisata birdwatching yang dapat memberikan manfaat bagi ekologi dan ekonomi masyarakat sekitar. Penelitian ini bertujuan untuk mengetahui jenis burung yang potensial dijadikan objek wisata birdwatching dan membandingkan dengan penelitian sebelumnya yang dilakukan oleh Triyanah pada tahun 2014, mengetahui pengaruh kondisi habitat dan tipe vegetasi terhadap keberadaan dan aktivitas burung, serta mengetahui persepsi masyarakat mengenai wisata birdwatching.

\section{METODE PENELITIAN}

Penelitian ini dilaksanakan pada bulan Oktober-November 2015 di lahan basah Desa Kibang Pacing Kecamatan Menggala Timur Kabupaten Tulang Bawang. Pengamatan burung dilakukan melalui metode observasi langsung dengan metode point count (Bibby, Jones dan Marsden, 2000). Pengamatan dilakukan pada tiga titik hitung (point count) di lokasi pengamatan pada pagi hari (Pukul 06.00 WIB-08.00 WIB) dan pada sore hari (Pukul 16.00 WIB -18.00 WIB). Seluruh stasiun pengamatan dibagi berdasarkan tiga tipe habitat yaitu 
pada vegetasi semak, kebun kelapa sawit, dan vegetasi gelam. Pengaruh tipe vegetasi dan kondisi habitat terhadap keberadaan dan aktivitas burung dilakukan dengan metode rapid assessment yang merupakan modifikasi dari habitat assessment untuk mendapatkan gambaran secara umum tipe vegetasi dan kondisi habitat ditemukannya burung (Brower, 1990). Persepsi masyarakat mengenai potensi wisata pengamatan burung diperoleh melalui wawancara semi terstruktur, tujuannya untuk menemukan permasalahan secara lebih terbuka. Pihak yang diwawancarai diminta pendapat dan ide-idenya (Sugiyono, 2007). Penentuan responden dilakukan dengan teknik snowball sampling. Snowball sampling adalah teknik pengambilan sampel dengan bantuan keyinforman yang mengetahui dan memiliki informasi tentang burung yang berada di sekitar lokasi penelitian.

Analisis data dilakukan melalui analisis deskriptif. Data hasil inventarisasi mengenai perjumpaan jumlah dan jenis burung kemudian ditabulasikan dalam bentuk tabel dan diidentifikasi jenis burung endemik menurut MacKinnon dkk. (2010). Selanjutnya diidentifikasi jenis burung yang dilindungi menurut Peraturan Pemerintah Nomor 7 Tahun 1999 tentang pengawetan jenis tumbuhan dan satwa, sebagai jenis burung yang potensial untuk dijadikan objek wisata birdwatching di Desa Kibang Pacing. Kemudian data perjumpaan jenis burung dibandingkan dengan data penelitian sebelumnya yang dilakukan oleh Triyanah pada tahun 2014 untuk melihat apakah ada perubahan jumlah jenis burung yang ditemukan di lokasi penelitian. Selanjutnya pengaruh tipe vegetasi dan kondisi habitat di lokasi penelitian terhadap keberadaan dan aktivitas burung dijabarkan berdasarkan tipe vegetasi dan kondisi habitat yang berbeda pada tiga titik lokasi pengamatan. Data persepsi masyarakat Desa Kibang Pacing mengenai wisata birdwatching diuraikan secara deskriptif dengan tujuan untuk menjelaskan keberadaan jenis burung yang diketahui oleh masyarakat, aktivitas masyarakat di sekitar lokasi penelitian, dan dukungan masyarakat terhadap wisata pengamatan burung (birdwatching).

\section{HASIL DAN PEMBAHASAN}

\section{Inventarisasi keberadaan jenis burung potensial yang dijadikan objek wisata birdwatching}

Hasil Inventarisasi keberadaan jenis burung yang telah dilakukan selama 9 hari di Lahan basah Desa Kibang Pacing Kecamatan Menggala Timur, ditemukan sebanyak 27 jenis burung dengan total 4171 individu yang berasal dari 11 famili. Sedangkan penelitian sebelumnya yang dilakukan oleh Triyanah pada tahun 2014, ditemukan sebanyak 40 jenis burung dengan total 1986 individu yang berasal dari 21 famili. Adapun daftar jenis burung selama penelitian yang terdapat di lahan Basah Desa Kibang Pacing disajikan pada Tabel 1.

Tabel 1. Daftar jenis burung yang terdapat di lahan basah Desa Kibang Pacing.

\begin{tabular}{lllccc}
\hline No & Nama Spesies & Suku dan Nama Latin & $\begin{array}{c}\text { Penelitian } \\
\text { Triyanah } \\
\mathbf{( 2 0 1 4 )}\end{array}$ & Status Perlindungan & $\begin{array}{c}\text { Status } \\
\text { Ekologi }\end{array}$ \\
\hline & & Ciconiidae & - & Dilindungi & Endemik \\
1 & Bangau bluwok & Mycteria cinerea & - & Tidak dilindungi & Endemik \\
2 & Bangau nganga & Anastomus oscitans & Dilindungi & Endemik \\
3 & Bangau sandang lawe & Ciconia episcopus & - & & \\
\hline
\end{tabular}


Lanjutan Tabel 1.

\begin{tabular}{|c|c|c|c|c|c|}
\hline No & Nama Spesies & Suku dan Nama Latin & $\begin{array}{c}\text { Penelitian } \\
\text { Triyanah } \\
\text { (2014) } \\
\end{array}$ & Status Perlindungan & $\begin{array}{l}\text { Status } \\
\text { Ekologi }\end{array}$ \\
\hline & & Ardeidae & & & \\
\hline 4 & Kuntul cina & Egretta eulophotes & - & Dilindungi & Endemik \\
\hline 5 & Kuntul besar & Egretta alba & $\sqrt{ }$ & Dilindungi & Endemik \\
\hline 6 & Kuntul kecil & Egretta garzetta & $\sqrt{ }$ & Dilindungi & Endemik \\
\hline 7 & Kuntul kerbau & Bubulcus ibis & $\sqrt{ }$ & Dilindungi & Endemik \\
\hline 8 & Blekok cina & Ardeola bacchus & - & Tidak dilindungi & Endemik \\
\hline 9 & Blekok sawah & Ardeola speciosa & $\sqrt{ }$ & Tidak dilindungi & Endemik \\
\hline 10 & Bambangan hitam & Dupetor flavicollis & - & Tidak dilindungi & Endemik \\
\hline \multirow[t]{2}{*}{11} & Cangak merah & Ardea purpurea & $\sqrt{ }$ & Tidak dilindungi & Endemik \\
\hline & & Alcedinidae & & & \\
\hline 12 & Pekaka emas & Pelargopsis capensis & - & Dilindungi & Endemik \\
\hline 13 & Cekakak belukar & Halcyon smyrnensis & $\sqrt{ }$ & Dilindungi & Endemik \\
\hline 14 & Cekakak sungai & Todirhamhus chloris & $\sqrt{ }$ & Dilindungi & Endemik \\
\hline 15 & Raja udang biru & Alcedo ceurulescens & - & Dilindungi & Endemik \\
\hline & & $\begin{array}{l}\text { Accipitridae } \\
\text { Ictinaetus malavensis }\end{array}$ & & & \\
\hline $\begin{array}{l}16 \\
17\end{array}$ & $\begin{array}{l}\text { Elang hitam } \\
\text { Elang bondol }\end{array}$ & $\begin{array}{l}\text { Ictinaetus malayensis } \\
\text { Haliastur indus }\end{array}$ & $\sqrt{y}$ & Dilindungi & Endemik \\
\hline 18 & Elang rawa kelabu & Circus cyaneus & - & Dilindungi & Endemik \\
\hline $\begin{array}{l}19 \\
20\end{array}$ & $\begin{array}{l}\text { Pecuk padi besar } \\
\text { Pecuk padi hitam }\end{array}$ & $\begin{array}{l}\text { Phalacrocoracidae } \\
\text { Phalacrocorax carbo } \\
\text { Phalacrocorax } \\
\text { sulcirostris }\end{array}$ & $\overline{\sqrt{ }}$ & $\begin{array}{l}\text { Tidak dilindungi } \\
\text { Tidak dilindungi }\end{array}$ & $\begin{array}{l}\text { Endemik } \\
\text { Endemik }\end{array}$ \\
\hline & & Rallidae & & & \\
\hline 21 & Mandar besar & Porphyrio porphyrio & $\sqrt{ }$ & Tidak dilindungi & Endemik \\
\hline 22 & Kareo padi & Amaurornis phoenicurus & $\sqrt{ }$ & Tidak dilindungi & Endemik \\
\hline 23 & Belibis kembang & $\begin{array}{l}\text { Anatidae } \\
\text { Dendrocygna arcuata }\end{array}$ & - & Tidak dilindungi & Endemik \\
\hline 24 & Bentet Kelabu & $\begin{array}{l}\text { Laniidae } \\
\text { Lanius schach }\end{array}$ & $\sqrt{ }$ & Tidak dilindungi & Endemik \\
\hline \multirow[t]{2}{*}{25} & Gagang bayam timur & $\begin{array}{l}\text { Recurvirostridae } \\
\text { Himantopus } \\
\text { leucocephalus }\end{array}$ & $\sqrt{ }$ & Tidak dilindungi & Endemik \\
\hline & & Threskiornithidae & & & \\
\hline 26 & Ibis cucuk besi & $\begin{array}{l}\text { Threskiornis } \\
\text { melanocephalus } \\
\text { Artamidae }\end{array}$ & $\sqrt{ }$ & Tidak dilindungi & Endemik \\
\hline 27 & Kekep babi & Artamus leucorhynchus & $\sqrt{ }$ & Tidak dilindungi & Endemik \\
\hline
\end{tabular}




\section{Vol. 5 No.I, Januari 2017 (35-46)}

Berdasarkan Tabel 1 diketahui bahwa seluruh burung tersebut merupakan burung endemik Sumatera, Jawa, Kalimantan, dan Bali (MacKinnon dkk., 2010). Sedangkan menurut PP No. 7 Tahun 1999 tentang Pengawetan Jenis Tumbuhan dan Satwa, hanya 13 jenis burung yang masuk kedalam kategori dilindungi. Berikut daftar jenis burung endemik dan dilindungi yang memiliki potensi dan daya tarik untuk dijadikan wisata birdwatching disajikan pada Tabel 2 .

Tabel 2. Daftar jenis burung endemik dan dilindungi yang memiliki potensi dan daya tarik wisata birdwatching.

\begin{tabular}{|c|c|c|c|}
\hline No & $\begin{array}{l}\text { Nama } \\
\text { Lokal }\end{array}$ & Nama Ilmiah & Daya Tarik \\
\hline 1 & $\begin{array}{l}\text { Bangau } \\
\text { bluwok }\end{array}$ & M. cinerea & $\begin{array}{l}\text { Panjang tubuh sekitar } 110 \mathrm{~cm} \text {, paruh besar dan } \\
\text { panjang, dominan warna tubuh putih, bercak hitam } \\
\text { di sayap primer dan muka botak berwarna merah } \\
\text { muda, kaki panjang berwarna merah muda. }\end{array}$ \\
\hline 2 & $\begin{array}{l}\text { Bangau } \\
\text { sandang } \\
\text { lawe }\end{array}$ & C. ерiscopus & $\begin{array}{l}\text { Tubuh berukuran sangat besar } 86 \mathrm{~cm} \text {, mahkota } \\
\text { hitam berkilap, seluruh leher berbulu seperti kapas } \\
\text { putih, sayap dan ekor hitam berkilau. }\end{array}$ \\
\hline 3 & $\begin{array}{l}\text { Kuntul } \\
\text { besar }\end{array}$ & E. alba & $\begin{array}{l}\text { Berukuran besar } 95 \mathrm{~cm} \text {, jauh lebih besar dari kuntul } \\
\text { putih lain, leher bersimpul khas. bulu-bulu halus di } \\
\text { tubuh. }\end{array}$ \\
\hline 4 & Kuntul kecil & E. garzetta & $\begin{array}{l}\text { Berukuran } 55 \mathrm{~cm} \text {, memiliki panjang bentangan } \\
\text { sayap } 88-106 \mathrm{~cm} \text {. Pada musim kawin, burung ini } \\
\text { mempunyai dua bulu hias putih yang tipis } \\
\text { memanjang pada tengkuknya. }\end{array}$ \\
\hline 5 & $\begin{array}{l}\text { Kuntul } \\
\text { kerbau }\end{array}$ & B. ibis & $\begin{array}{l}\text { Seluruh bulunya berwarna putih, tetapi selama } \\
\text { musim kawin, bulu-bulu pada kepala,leher dan } \\
\text { punggungnya berwarna kuning jingga. }\end{array}$ \\
\hline 6 & Kuntul cina & E. eulophotes & $\begin{array}{l}\text { Berukuran sedang } 68 \mathrm{~cm} \text {, berwarna putih dengan } \\
\text { kaki kehijauan, paruh hitam dengan pangkal bawah } \\
\text { kuning. }\end{array}$ \\
\hline 7 & $\begin{array}{l}\text { Cekakak } \\
\text { belukar }\end{array}$ & H. smyrnensis & $\begin{array}{l}\text { Berukuran sekitar } 27 \mathrm{~cm} \text {. Dominan berwarna } \\
\text { coklat dan biru, dengan dagu, kerongkongan dan } \\
\text { dada berwarna putih. }\end{array}$ \\
\hline 8 & $\begin{array}{l}\text { Cekakak } \\
\text { sungai }\end{array}$ & T. chloris & $\begin{array}{l}\text { Berukuran sedang } 24 \mathrm{~cm} \text {, warna biru dan putih. } \\
\text { Mahkota, sayap, punggung, dan ekor biru kehijauan } \\
\text { berkilau terang. }\end{array}$ \\
\hline 9 & $\begin{array}{l}\text { Pekaka } \\
\text { emas }\end{array}$ & P. capensis & $\begin{array}{l}\text { Berukuran } 35 \mathrm{~cm} \text {, ciri khas: punggung biru dengan } \\
\text { paruh besar berwarna merah mencolok. }\end{array}$ \\
\hline 10 & $\begin{array}{l}\text { Raja udang } \\
\text { biru }\end{array}$ & A. ceurulescens & $\begin{array}{l}\text { Berukuran } 14 \mathrm{~cm} \text {, tubuh bagian atas dan garis dada } \\
\text { biru kehijauan mengkilap. }\end{array}$ \\
\hline 11 & Elang hitam & I. malayensis & $\begin{array}{l}\text { Berukuran } 70 \mathrm{~cm} \text {, sayap dan ekornya panjang, } \\
\text { sehingga burung ini tampak sangat besar saat } \\
\text { terbang. }\end{array}$ \\
\hline
\end{tabular}


Lanjutan Tabel 2.

\begin{tabular}{|c|c|c|c|}
\hline No & Nama Lokal & Nama Ilmiah & Daya Tarik \\
\hline 12 & $\begin{array}{l}\text { Elang rawa } \\
\text { kelabu }\end{array}$ & C.cyaneus & $\begin{array}{l}\text { Berukuran besar } 70 \mathrm{~cm} \text {, ekor coklat mengkilap } \\
\text { dengan ujung bergaris hitam. Jarang terbang } \\
\text { melayang tinggi }\end{array}$ \\
\hline 13 & Elang bondol & H. indus & $\begin{array}{l}\text { Berkuran sedang } 43-51 \mathrm{~cm} \text {, memiliki sayap yang } \\
\text { lebar dengan ekor pendek dan membulat ketika } \\
\text { membentang. }\end{array}$ \\
\hline
\end{tabular}

Bangau bluwok (M. cinerea) merupakan burung air yang ditemukan diseluruh titik pengamatan dengan aktivitas istirahat dan mencari makan. Burung ini pada pagi hari berada di tepi kanal dengan aktivitas mencari makan. Daerah tersebut memiliki sumber pakan yang cukup melimpah. Sedangkan pada sore hari, burung tersebut ditemukan pada titik pengamatan vegetasi gelam dengan aktivitas istirahat. Menurut Jumilawaty (2011) mengungkapkan bahwa burung air akan senang mencari makan pada lahan dengan sumber pakan yang melimpah dan beristirahat pada vegetasi yang berada tidak jauh pada lahan tersebut.

Kuntul besar (E. alba) ditemukan di 3 (tiga) titik lokasi pengamatan yaitu titik pengamatan vegetasi semak, vegetasi gelam, dan vegetasi sawit. Burung kuntul pada vegetasi semak ditemukan sebanyak 206 perjumpaan, sedangkan pada vegetasi gelam dan sawit masing-masing sebanyak 155 dan 77 perjumpaan. Untuk aktivitas mencari makan, burung ini ditemukan sebanyak 161 perjumpaan di pagi hari, sedangkan aktivitas pindah ditemukan sebanyak 161 perjumpaan di sore hari.

Berdasarkan pengamatan dilapangan, Kuntul besar (E. alba) lebih sering ditemukan di tepi kanal pada pagi hari dengan aktivitas mencari makan dan terlihat mencari makan dan terbang dengan kelompok jenis burung lain seperti kuntul kecil, kuntul kerbau, dan bangau sandanglawe. Sebagaimana yang diungkapkan oleh Jumilawaty (2011) bahwa, kuntul senang mencari makan berkelompok baik dengan kelompok sesama kuntul maupun dengan burung jenis burung lain seperti burung cangak dan burung bluwok tanpa terlihat adanya persaingan.

Kuntul kecil (E. garzetta) ditemukan di seluruh titik pengamatan sebanyak 399 perjumpaan. Burung ini paling banyak ditemukan pada titik pengamatan sawit dengan jumlah 177 perjumpaan, sedangkan pada vegetasi semak dan gelam masing-masing ditemukan sebanyak 126 dan 96 perjumpaan. Untuk aktivitas mencari makan, burung ini ditemukan sebanyak 206 perjumpaan di pagi hari, sedangkan aktivitas pindah ditemukan sebanyak 193 perjumpaan di sore hari.

Berdasarkan pengamatan dilapangan, kuntul kecil lebih sering ditemukan di tepi kanal dengan aktivitas mencari makan. Kemudian burung tersebut beraktivitas istirahat dengan cara bertengger di pohon gelam. Selain itu, burung tersebut dapat terbang bersama jenis burung lain yaitu kuntul kerbau, kuntul besar, blekok cina, dan blekok sawah. Menurut MacKinnon dkk. (2010) menyatakan bahwa kuntul kecil biasanya terbang untuk mengunjungi sawah, tepi sungai, gosong pasir, lumpur, dan sungai kecil. Burung tersebut terbang dalam formasi huruf V sehingga memiliki daya tarik tersendiri bagi burung tersebut.

Kuntul kerbau (B. ibis) dijumpai di seluruh titik penelitian dengan total perjumpaan sejumlah 340 individu. Burung ini lebih sering dijumpai pada pagi hari dengan jumlah 178 perjumpaan, sedangkan pada sore hari sejumlah 162 perjumpaan. Burung ini paling banyak dijumpai dengan aktivitas mencari makan pada pagi hari sejumlah 140 perjumpaan, berpindah sejumlah 30 perjumpaan dan istirahat 8 perjumpaan. Sedangkan pada sore hari 
lebih banyak dijumpai dengan aktivitas pindah sejumlah 82 perjumpaan, mencari makan sejumlah 80 perjumpaan. Burung ini paling banyak ditemukan pada titik pengamatan gelam dengan jumlah 166 perjumpaan, pada titik pengamatan sawit sejumlah 146 perjumpaan, dan pada titik pengamatan semak ditemukan sejumlah 28 perjumpaan.

Berdasarkan pengamatan dilapangan, kuntul kerbau lebih sering ditemukan mencari makan dan bermain dengan kerbau dan sapi, sesekali burung ini terlihat hinggap dan terbang bersama jenis burung lain namun tetap memiliki ciri khas tersendiri sebagai pembeda dari jenis lainnya seperti paruh kuning dan memiliki tubuh tegap. Menurut MacKinnon dkk. (2010), kuntul kerbau sangat mudah dibedakan dari kuntul lainnya karena tubuh lebih tegap, leher lebih pendek, kepala lebih bulat, serta paruh lebih pendek dan tebal, iris kuning, paruh kuning, dan kaki hitam. Waktu berbiak, kuntul kerbau berwarna putih, dengan kepala, leher, dan dada jingga pupus dengan iris, kaki, dan kekang merah terang. Burung ini biasanya suka bergabung di padang rumput dengan sapi, kerbau, atau banteng, tempat mereka menangkap lalat. Setiap sore, kelompok-kelompok kecil terbang rendah dalam barisan di atas air menuju tempat beristirahat.

Bangau sandang lawe (C. episcopus) selama penelitian ditemukan pada 2 (dua) titik pengamatan yaitu: pada titik pengamatan vegetasi gelam dan kebun kelapa sawit. Burung ini pada titik pengamatan vegetasi gelam ditemukan dengan aktivitas mencari makan pada waktu pagi hari, sedangkan pada titik pengamatan kebun kelapa sawit burung ini ditemukan dengan aktvitas pindah pada waktu sore hari. Menurut Jumilawaty (2004), burung air yang sedang mencari makan berpindah dari satu lokasi ke lokasi lainnya untuk memperoleh makan dan mengeksploitasi makanan sesuai dengan kebutuhan hidupnya.

Kuntul cina (E. eulophotes) selama penelitian paling banyak ditemukan pada titik penelitian vegetasi gelam dengan aktivitas mencari makan, sedangkan pada sore hari paling banyak ditemukan pada titik penelitian vegetasi semak dengan aktivitas pindah. Menurut Elfidasari (2005), aktivitas mencari makan meliputi melangkah, berhenti melangkah, mematuk mangsa, memegang mangsa, menelan mangsa, minum, berinteraksi dengan individu lain sejenis (intraspesies) atau dengan individu lain dari jenis yang berbeda (interspesies). Selain itu berhasil pula dicatat aktivitas lain yang tidak berhubungan dengan mencari makan tetapi dilakukan pada saat aktivitas mencari makan atau di lokasi mencari makan seperti membersihkan bulu dan membuang kotoran. Burung ini dapat dilihat dengan jarak paling dekat 15 meter.

Cekakak belukar ditemukan di seluruh titik penelitian dengan jumlah 47 perjumpaan. Ditemukan pada pagi hari sejumlah 20 perjumpaan dengan aktivitas mencari makan sejumlah 13 perjumpaan dan istirahat sejumlah 7 perjumpaan, sedangkan pada sore hari burung ini ditemukan dengan jumlah 27 perjumpaan dengan aktivitas mencari makan sejumlah 14 perjumpaan, berpindah sejumlah 11 perjumpaan dan istirahat 2 perjumpaan.

Cekakak belukar paling banyak ditemukan pada titik pengamatan sawit dengan jumlah 25 perjumpaan, sedangkan pada titik pengamatan semak sejumlah 18 perjumpaan, dan pada titik pengmatan gelam ditemukan sejumlah 4 perjumpaan. Burung ini dapat dilihat sampai jarak terdekat \pm 14 meter.

Cekakak sungai ditemukan di 3 (tiga) titik penelitian yaitu: pada titik pengamatan vegetasi gelam, vegetasi semak, dan kebun kelapa sawit. Titik pengamatan vegetasi semak dan titik pengamatan vegetasi gelam ditemukan dengan jumlah masing-masing 16 perjumpaan, sedangkan pada titik pengamatan sawit sejumlah 12 perjumpaan.

Burung ini pada waktu pada pagi hari ditemukan sebanyak 18 perjumpaan dengan aktivitas istirahat sebanyak 8 perjumpaan, mencari makan sebanyak 7 perjumpaan, dan pindah sebanyak 3 perjumpaan, sedangkan sore hari burung ditemukan sebanyak 27 perjumpaan dengan aktivitas mencari makan sebanyak 22 perjumpaan, berpindah sejumlah 3 
perjumpaan, dan istirahat 2 perjumpaan. Burung ini paling banyak Peneliti dapat mengamati burung ini sampai jarak terdekat \pm 14 meter.

Cekakak sungai (T. chloris ) selama penelitian lebih sering ditemukan hinggap di putri malu sambil bersiap terbang dan menangkap ikan di tepi kanal. Menurut Elfidasari (2005), burung ini biasanya terbang di sekitar mangsa atau berdiri mengamati mangsa dari atas dahan atau tempat yang tinggi, kemudian akan menukik masuk ke dalam air untuk menangkap mangsa yang sedang berenang. Perbedaan pola dan cara memperoleh mangsa ini diduga mampu menciptakan kebersamaan antara beberapa jenis burung untuk dapat hidup dan mencari mangsa bersama-sama pada waktu dan lokasi yang sama. Kebiasaan burung ini mengunjungi daerah terbuka dan bertengger pada bebatuan atau pohon.

Pekaka emas ( $P$. capensis) selama penelitian ditemukan pada dua titik pengamatan yaitu: pada titik pengamatan vegetasi semak dan vegetasi gelam. Ditemukan pada waktu sore hari dengan aktivitas mencari makan, sedangkan pada pagi hari ditemukan dengan aktivitas istirahat. Pengguanaan habitat burung ini pada pengamatan di lapangan lebih banyak di titik pengamatan vegetasi gelam. Menurut Wiharyanto (1996), tingkat keseringan burung liar menggunakan jenis tumbuhan merupakan salah satu kriteria untuk menunjukkan tingkat ketergantungan burung dalam menggunakan suatu habitat untuk melakukan aktivitas.

Raja udang biru (A. ceurulescens) selama penelitian lebih sering melakukan aktivitas pindah pada pagi hari, sedangkan pada sore hari burung ini lebih sering melakukan aktivitas istirahat pada titik penelitian vegetasi semak. Burung ini paling sedikit ditemukan pada lokasi penelitian. Menurut Darmawan (2006), burung yang hanya ditemukan pada satu atau beberapa habitat saja dimungkinkan karena jenis tersebut hanya mampu menempati tipe habitat tertentu atau dikarenakan jenis tersebut memiliki populasi yang cukup rendah.

Elang hitam (I. malayensis ) ditemukan pada 3 (tiga) titik pengamatan yaitu: pada titik pengamatan vegetasi gelam, vegetasi semak, dan kebun kelapa sawit. sebanyak 15 perjumpaan. Burung ini paling banyak ditemukan pada titik pengamatan gelam dengan jumlah 10 perjumpaan, sedangkan pada titik pengamatan semak sebanyak 4 perjumpaan, dan pada titik pengamatan sawit ditemukan sebanyak 1 perjumpaan. Sore hari burung ini ditemukan sebanyak 13 perjumpaan, sedangkan pada pagi hari sebanyak 2 perjumpaan.

Burung ini paling banyak ditemukan pada pagi hari dengan aktivitas istirahat sebanyak 2 perjumpaan, sedangkan pada sore hari dengan aktivitas pindah sebanyak 10 perjumpaan dan sebanyak 3 perjumpaan istirahat. Aktivitas burung ini didominasi oleh aktivitas berpindah dengan cara terbang berputarputar diatas tajuk pohon gelam. Menurut MacKinnon dkk. (2010), elang hitam biasanya ditemukan berputar-putar rendah di atas tajuk pohon, kemudian meluncur dengan indah. Burung ini dapat dilihat sampai jarak terdekat \pm 14 meter.

Elang rawa kelabu (C.cyaneus) ditemukan pada titik pengamatan semak dan titik pengamatan gelam sebanyak 7 perjumpaan. Burung ini lebih sering ditemukan pada pagi hari sebanyak 4 perjumpaan dengan aktivitas pindah sebanyak 4 individu., sedangkan pada sore hari ditemukan sebanyak 3 perjumpaan dengan aktivitas berpindah sebanyak 2 perjumpaan dan aktivitas istirahat sebanyak 1 perjumpaan. Menurut Sawitri (2010), aktivitas istirahat lebih banyak dilakukan setelah makan dengan posisi tubuh bertengger, bagian ventral merunduk, kedua kaki mencengkeram erat pada kayu atau tenggeran dan kedua mata terpejam.

Elang bondol (H. indus ) ditemukan pada titik pengamatan sawit dan titik pengamatan gelam sejumlah 5 perjumpaan. Pagi hari burung ini ditemukan dengan jumlah 3 perjumpaan dengan aktivitas istirahat sebanyak 2 perjumpaan dan pindah sebanyak 1 perjumpaan, sedangkan pada sore hari burung ini ditemukan sebanyak 2 perjumpaan dengan aktivitas pindah. Burung ini paling banyak ditemukan pada titik pengamatan gelam sebanyak 4 perjumpaan, sedangkan pada titik pengamatan kebun kelapa sawit sejumlah 1 perjumpaan. 
Selama pengamatan burung ini ditemukan terbang rendah disekitar titik pengamatan dan terlihat hinggap dipohon gelam dan sampai waktu \pm 20 menit untuk melihat kondisi sekitar dan mencari mangsa. Umumnya burung pemangsa menggunakan dua cara untuk menangkap mangsanya dimana pemakan ikan menangkap mangsa menggunakan paruh sedangkan burung pemangsa lainnya menggunakan cakar untuk mencengkeram mangsa dan paruh digunakan untuk mencabik mangsa (Burnie, 1992).

Keberadaan burung dilokasi penelitian semakin berkurang. Ditemukan sejumlah 27 jenis burung pada penelitian ini sedangkan pada penelitian sebelumnya yaitu Triyanah 2014 ditemukan sejumlah 40 jenis burung. Kondisi tersebut disebabkan kurangnya sumber pakan bagi burung. Masyarakat sekitar lokasi menangkap ikan yang menjadi pakan burung, meskipun masyarakat masih menunakan cara-cara tradisional yaitu dengan cara memancing dan menjaring. Sumber pakan merupakan hal yang utama bagi keberadaan burung pada suatu habitat (Napitu, 2007). Selain itu kebakaran lahan menyebabkan tempat istirahat, berlindung, dan berkembang biak burung menjadi rusak. Menurut Elfidasari dan Junardi (2005), kelimpahan burung pada suatu lokasi disebabkan karena burung tersebut mampu menciptakan relung khusus bagi dirinya sendiri untuk mengurangi kompetisi atas sumber daya dan berbagai bentuk adaptasi terhadap kondisi lingkungan.

\section{Pengaruh tipe vegetasi dan kondisi habitat terhadap keberadaan dan aktivitas burung di lokasi penelitian}

Pengaruh tipe vegetasi dan kondisi habitat terhadap keberadaan dan aktivitas burung di lokasi penelitian dapat dilihat melalui keberadaan dan aktivitas burung pada tiga titik penelitian yang masing-masing titik penelitian mewakili 3 tipe vegetasi dan kondisi habitat pada lokasi penelitian disajikan pada Tabel 3.

Tabel 3. Keberadaan dan aktivitas burung pada tiga titik pengamatan di lahan basah Desa Kibang Pacing Kecamatan Menggala Timur Kabupaten Tulang Bawang.

\begin{tabular}{llcccc}
\hline No. & Titik Penelitian & \multicolumn{3}{c}{ Aktivitas Burung } & \multirow{2}{*}{$\begin{array}{c}\text { Jumlah } \\
\text { Perjumpaan } \\
\text { Burung }\end{array}$} \\
\cline { 3 - 5 } & Makan & Istirahat & Pindah & 1.338 \\
\hline 1. & $\begin{array}{l}\text { Titik pengamatan pada } \\
\text { vegetasi semak }\end{array}$ & 650 & 268 & 420 & 1.335 \\
2. $\quad \begin{array}{l}\text { Titik pengamatan pada } \\
\text { kebun kelapa sawit } \\
\text { Titik pengamatan pada } \\
\text { vegetasi gelam }\end{array}$ & 405 & 192 & 738 & 1.498 \\
\hline
\end{tabular}

Kondisi titik pengamatan vegetasi semak jauh dari aktivitas manusia. Titik pengamatan ini terdapat sumber pakan berupa kanal. Jenis vegetasi pada titik pengamatan ini adalah putri malu dan rumput alas. Di sisi lain kondisi pada titik pengamatan kebun kelapa sawit tidak terdapat pohon sebagai tempat berlindung dan istirahat serta sumber pakan yang tersedia tidak melimpah, kanal sekitar lokasi titik pengamatan sudah hampir kering sehingga keberadaan burung pada titik ini paling sedikit. Suatu jenis burung biasanya memerlukan kondisi lingkungan dan jenis makanan yang spesifik (Hadinoto, 2012). Di sisi lain kondisi habitat pada titik pengamatan gelam terdapat sumber pakan dan jauh dari gangguan ataupun aktivitas masyarakat. Sumber pakan pada titik ini yaitu kanal yang masih banyak air dengan 
tipe vegetasi hutan gelam sebagai tempat berlindung dari predator, sebagai tempat istirahat dan bermain. Habitat yang kondisinya baik dan jauh dari gangguan manusia serta di dalamnya mengandung bermacam-macam sumber pakan, memungkinkan memiliki jenis burung yang banyak (Widodo, 2009).

Pengamatan dilakukan dengan mencatat perjumpaan burung dan aktivitasnya pada setiap titik pengamatan. Pada titik pengamatan semak burung lebih banyak dijumpai mencari makan ditepi kanal, selain itu burung dijumpai terbang di sekitar lokasi pengamatan kearah barat dan utara, dan burung dijumpai hinggap dan bermain di vegetasi semak. Di sisi lain pada titik pengamatan kebun kelapa sawit burung lebih banyak melakukan aktivitas pindah, burung lebih sering terlihat terbang di sekitar titik menuju kearah timur. Di sisi lain pada titik pengamatan vegetasi gelam burung lebih sering melakukan aktivitas istirahat dan aktivitas makan. Pada titik pengamatan ini burung lebih sering dijumpai mencari makan di tepi kanal dan hinggap, bermain, dan berlindung pada vegetasi gelam. Menurut Syahadat, Erianto, dan Siahaan (2015) bahwa burung cenderung akan memilih struktur vegetasi yang baik dan terlindung, sehingga burung merasa lebih aman untuk beraktivitas. Kondisi habitat dan tipe vegetasi berpengaruh terhadap keberadaan dan aktivitas burung, jika kondisi habitatnya rusak maka keberadaan burung pada lokasi penelitian akan berkurang, sehingga akan berpengaruh terhadap keberlangsungan wisata birdwatching. Menurut Rohiyan (2014), burung akan memilih habitat yang memiliki kelimpahan sumberdaya bagi kelangsungan hidupnya, sebaliknya jarang atau tidak ditemukan pada lingkungan yang kurang menguntungkan baginya. Aktivitas burung pada setiap titik pengamatan disajikan dalam Gambar 1.

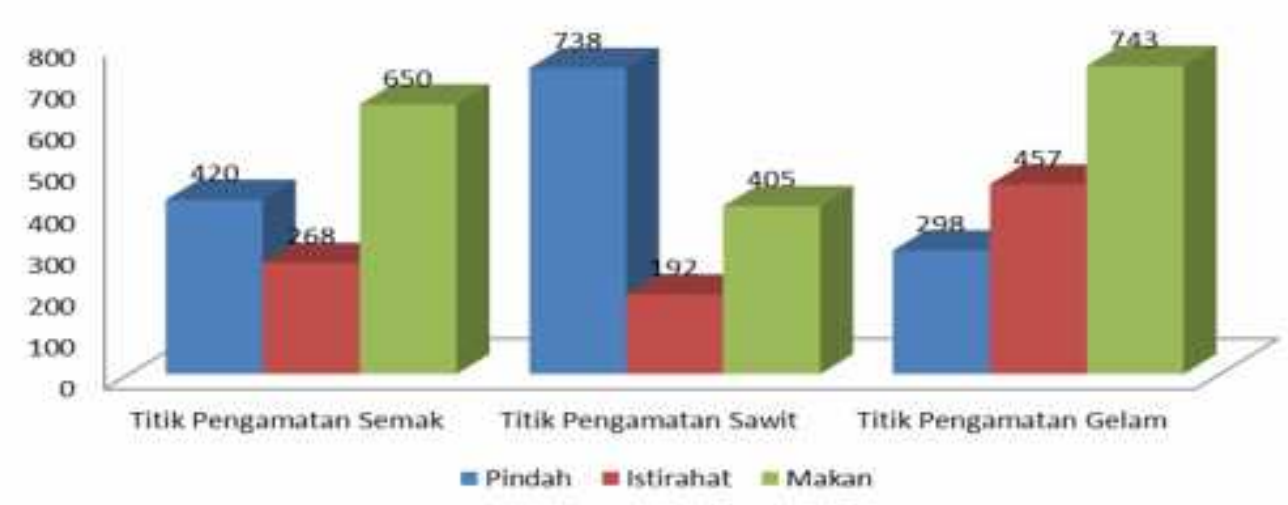

Gambar 1. Diagram aktivitas burung pada setiap titik pengamatan.

\section{Persepsi masyarakat Desa Kibang Pacing Kecamatan Menggala Timur mengenai wisata birdwatching}

Persepsi masyarakat Desa Kibang Pacing Kecamatan Menggala Timur mengenai wisata birdwatching diantaranya menjelaskan keberadaan jenis burung yang diketahui masyarakat, aktivitas masyarakat di sekitar lokasi penelitian, dan dukungan masyarakat terhadap wisata pengamatan burung. Berdasarkan hasil wawancara dengan 18 sampel masyarakat diperoleh informasi bahwa jenis burung yang diketahui masyarakat adalah: bangau bluwok dan cekakak sungai. Kedua jenis tersebut ditemukan dilokasi penelitian, sehingga tidak menambah informasi baru tentang keberadaan jenis burung dilokasi penelitian. Masyarakat yang mengetahui burung tersebut sejumlah 6 orang atau 33\% dari total sampel. Sedangkan aktivitas masyarakat disekitar lokasi penelitian adalah: memancing, menjaring, mengambil rumput dan berkebun. Sejumlah 9 orang sampel memancing, 4 orang menjaring, 2 orang 
mengambil rumput, dan 3 orang berkebun. Kegiatan masyarakat mempengaruhi aktivitas burung pada lokasi penelitian akan tetapi tidak terlalu mengancam keberadaan burung, karena masyarakat tidak menggunakan pestisida secara berlebihan untuk berkebun dan menangkap ikan menggunakan jaring yang tidak meracuni ikan pada kanal. Seluruh sampel masyarakat mendukung jika nantinya ada pengembangan wisata pengamatan burung di Desa Kibang Pacing. Masyarakat menyatakan siap untuk berperan aktif dalam hal pendampingan wisatawan, penyediaan penginapan dan makanan yang sesuai dengan kemampuan masyarakat. Persepsi masyarakat mengenai wisata birdwatching disajikan pada Gambar 2.
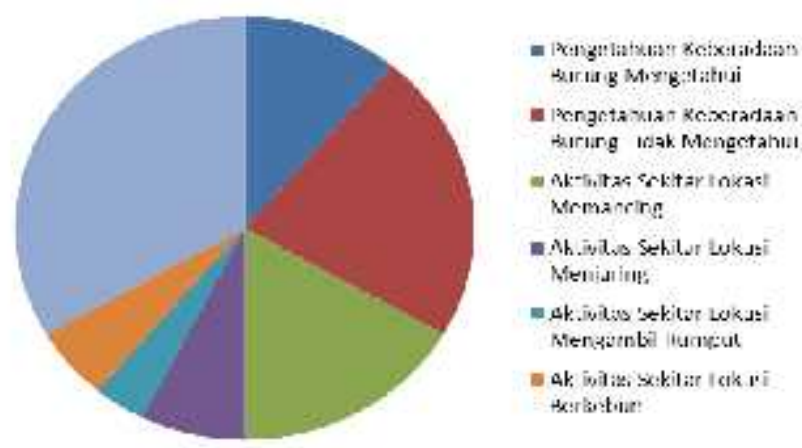

Gambar 2. Diagram Persepsi masyarakat mengenai wisata birdwatching.

\section{SIMPULAN}

Berdasarkan hasil penelitian yang telah dilakukan diperoleh simpulan sebagai berikut:

1. Lahan basah Desa Kibang Pacing memiliki burung yang potensial untuk dijadikan wisata birdwatching sebanyak 13 jenis diantaranya adalah bangau bluwok ( $M$. cinerea), bangau sandang lawe (C. episcopus), kuntul besar (E. alba), kuntul kecil (E. garzetta), kuntul kerbau (B. ibis), kuntul cina (E. eulophotes), cekakak belukar (H. smyrnensis), cekakak sungai (T. chloris), pekaka emas (P. capensis), raja udang biru (A. ceurulescens), elang hitam (I. malayensis), elang rawa kelabu (C.cyaneus), dan elang bondol (H. indus).

2. Kondisi habitat dan tipe vegetasi di lahan basah Desa Kibang Pacing sangat berpengaruh terhadap keberadaan dan aktivitas burung. Keberadaan burung paling banyak ditemukan pada tipe vegetasi gelam yang kondisi habitatnya baik dengan sumber pakan yang melimpah sehingga akvitas burung ditemukan paling banyak mencari makan. Jika kondisi habitatnya rusak maka keberadaan burung pada lokasi penelitian akan berkurang, sehingga akan berpengaruh terhadap keberlangsungan wisata birdwatching.

3. Masyarakat mendukung sepenuhnya untuk pengembangan wisata birdwatching. 


\section{DAFTAR PUSTAKA}

Bibby, C., M. Jones, dan S. Marsden. 2000. Teknik Ekspedisi Lapang: Survei Burung. Buku. BirdLife International-Indonesia Programme. Bogor. 178 p.

Elfidasari, D., dan Junardi. 2005. Keanekaragaman jenis burung air di kawasan Hutan Mangrove Peniti Kabupaten Pontianak. Jurnal Biodiversitas. 7(1). 63-66.

Hadinoto., A. Mulyadi, dan Y. I. Siregar. 2012. Keanekaragaman jenis burung di Hutan Kota Pekanbaru. Jurnal Ilmu Lingkungan. 6(1):25-42.

Jumilawaty, E., Ani, M., Lilik, B., dan Yeniaryati M. 2011. Keanekaragaman burung air di Bagan Percut, Deli Serdang Sumatera Utara. Jurnal Media Konservasi. 16(3): 108 113.

Mac Kinnon, J., K. Philipps, dan B. Van Balen. 2010. Seri Panduan Lapangan BurungBurung di Sumatera, Jawa, Bali, dan Kalimantan. Buku. LIPI. Bogor. 509 p.

Napitu, J. P. 2007. Pengelolaan kawasan konservasi. Laporan Lapang. UGM. Yogyakarta. $12 \mathrm{p}$.

Natarino, A. 2010. Studi keanekaragaman jenis burung sebagai pengembangan potensi wisata birdwatching di Wilayah Kelola Shk Lestari Tahura Wan Abdul Rahman. Skripsi. Universitas Lampung. Bandar Lampung. 67 p.

Rohiyan, M., A. Setiawan, dan E. L. Rustiati. 2014. Keanekaragaman jenis burung di hutan pinus dan hutan campuran Muarasipongi Kabupaten Mandailing Natal Sumatera Utara. Jurnal Sylva Lestari II (2): 89-98.

Sawitri, R., dan Mariana, T. 2010. Pengelolaan dan perilaku burung elang di Pusat Penyelamatan Satwa Cikananga, Sukabumi. Jurnal Penelitian Hutan Dan Konservasi Alam. VII ( 3). 257-270.

Sugiyono. 2011. Metode Penelitian Kuantitatif, kualitatif dan $R \& D$. Alfabeta: Buku. Bandung. 380 p.

Sukara, G. N., Y. A. Mulyani, dan E. K. Muntasib. 2014. Potensi untuk pengembangan wisata birdwatching di Pusat Konservasi Tumbuhan Kebun Raya Bogor. Jurnal Buletin Kebun Raya. 17(1): 45-51.

Syahadat. F., Erianto, dan S., Siahaan. 2015. Studi keanekaragaman jenis burung diurnal di Hutan Mangrove Pantai Air Mata Permai Kabupaten Ketapang. Jurnal Hutan Lestari. $3(1): 21-29$.

Triyanah, E. 2014. Biodiversitas burung di Desa Kibang Pacing Kecamatan Menggala Timur Kabupaten Tulang Bawang Provinsi Lampung. Skripsi. Universitas Lampung. Bandar Lampung. 91 p.

Widodo, W. 2009. Komparasi keragaman jenis burung-burung di Taman Nasional Baluran dan Alas Purwo pada beberapa tipe habitat. Jurnal Berkala Penelitian Hayati. (14). 113-124.

Widyasari, K., L. Hakim, dan B. Yanuwiadi. 2013. Kajian jenis - jenis burung di Desa Ngadas sebagai dasar perencanaan jalur pengamatan burung (birdwatching). Journal of Indonesian Tourism and Development Studies. 3(I): 108-109. 